\title{
The use of vyazolistnogo labaznik (Filipendula ulmaria (L.) Maxim) to increase the antioxidant activity of hepatoprotective collection of plant origin
}

\author{
(C) Anatoly A. Lapin, ${ }^{1}{ }^{+}$and Valery N. Zelenkov ${ }^{2.3}$ \\ ${ }^{1}$ Kazan State Power Engineering University. Krasnoselskaya St., 51. Kazan, 420066. Republic of Tatarstan. \\ Russia.Phone: +7 (843) 519-42-67.E-mail: lapinanatol@mail.ru \\ ${ }^{2}$ All-Russian Research Institute of Medicinal and Aromatic Plants. Green St., 7. Moscow, 117216. \\ Russia.E-mail: zelenkov-raen@mail.ru \\ ${ }^{3}$ All-Russian Scientific Research Institute of Vegetable Growing - the branch of FSBSI "Federal \\ Scientific Vegetable Center”. 500 Vereya Village. Ramenskoe district, 140153. Moscow Region. Russia.
}

\begin{abstract}
*Supervising author; ${ }^{+}$Corresponding author
Keywords: antioxidant activity, total antioxidant activity, coulometric analysis method, synergy hepatoprotectors of plant origin.
\end{abstract}

Abstract
Currently available on the pharmaceutical market drugs do not fully have high antioxidant activity, so the search for new means to prevent and eliminate liver damage is relevant. The purpose of this study was to evaluate the use of vyazolistnogo labaznik to increase the antioxidant activity of hepatoprotective collections of plant origin. Water extracts of hepatoprotective collection (GPS) have significant antioxidant activity, which is reflected by its linear dependence on the amount of GPS taken for extraction with a confidence value of approximation $\mathrm{R}^{2}$ of 0.989. Total antioxidant activity (TAA) the collection infusion increased from 0.690 to $4.883 \mathrm{~g}$ of rutin (Ru) per $1 \mathrm{dm}^{3}$ when brewing from $5 \mathrm{~g}$ to $40 \mathrm{~g}$ of collection per 1 liter of boiling water, while the linear dependence twice reaches the plateau when the amount of collection taken for extraction is $10-12 \mathrm{~g}$ and $18-21 \mathrm{~g}$, the TAA of GPS infusions was $1.35 \pm 0.004$ and $2.26 \pm 0.11 \mathrm{~g}$ of Ru per $1 \mathrm{dm}^{3}$. To increase the TAA of the water extract of GPS, an aqueous extract of dried flowers of elmberry (Filipendula ulmaria (L.) Maxim) was used, obtained in a similar way. The TAA of water extracts of GPS as the labasnik extract was added increased to its content of $30 \% \mathrm{wt}$., and the effects of synergy $\left(\mathrm{TAA}^{\text {excess }}\right.$ ) - decreased to 0 (labasnik content of $35 \% \mathrm{wt}$ ), passing into antagonism according to the linear equation with a confidence value of approximation $\mathrm{R}^{2} 0.981$. Comparative tests of water extracts of laburnum flowers and GPS in closed containers for storing biological samples at a temperature of $+5{ }^{\circ} \mathrm{C}$ in the refrigerator showed that the TAA of water extraction of laburnum flowers in $\mathrm{g}$ Ru by $1 \mathrm{dm} 3$ from the number of days of its aging decreases according to the linear equation with the approximation confidence value $\mathrm{R}^{2} 0.927$, and GPS increases $-\mathrm{R}^{2} 0.965$.

\section{References}

[1] A.A. Lapin, M.S. Talan, and I.S. Dokuchaeva. On the issue of standardization of dry extract "Glyzyrrhiza 7" Biochemical study of insects used in fish feed for antioxidant activity. Butlerov Communications. 2019. Vol.58. No.6. P.91-96. DOI: $10.37952 / R O I-j b c-03 / 19-59-7-91$

[2] A.A. Lapin, I.G. Garifullin, S.D. Litvinov. Antioxidant properties of hepatoprotective collection. Bulletin of the medical institute "REAVIZ": rehabilitation, doctor and health. 2019. No.5(41). P.202-207 (russian)

[3] E.A. Ushkalova. Problems of using hepatoprotectors. Farmateka. 2004. No.4. P.45-55. (russian)

[4] E.V. Ferubko, V.N. Zelenkov, A.A. Lapin, T.D. Dargaeva. The study of the antioxidant activity of the collection of antihepatoxic action and its constituent components. Proceedings of the II International Scientific Conference "The role of metabolomics in improving biotechnological means of production" (Moscow, June 6-7, 2019, FGBNU VILAR). Moscow: VILAR. 2019. 615p. P.77-81. (russian)

[5] V.A. Smirnov, V.V. Smirnova. Modern methods for measuring the antioxidant activity of biological objects. Almanac of modern metrology. 2015. No.2. P.248-279. (russian)

[6] T.V. Sambukova, B.V. Ovchinnikov, V.P. Ganapolsky, A.N. Yatmanov, P.D. Shabanov. Prospects for the use of herbal remedies in modern pharmacology. Clinical pharmacology and drug therapy reviews. 2017. Vol.15. No.2. P.56-63. Doi: 10.17816/RCF15256-63 
THE USE OF VYAZOLISTNOGO LABAZNIK (Filipendula ulmaria (L.) Maxim) TO INCREASE THE ANTIOXIDANT... $112-119$

[7] I.G. Nikolaeva. Development and standardization of herbal products with adaptogenic activity: $A b s t r a c t$. dis. ... Dr. pharmacist. sciences. Ulan-Ude. 2012. 48p. (russian)

[8] V.S. Baranova, I.F. Rusina, D.A. Guseva, N.N. Prozorovskaya, O.M. Ipatova, O.T. Kasaikina. The antiradical activity of plant extracts and hyeal thful prevetntive combinations of these extracts with the phospholipid complex. Biomedical Chemistry. 2012. Vol.58. P.712-726. (russian)

[9] A.V. Pogrebnyak, E.F. Stepanova. Quantum-chemical modeling of the process of sorption of medicinal substances and the immobilization of phytocomponents in dosage forms. Chemical Pharmaceutical Journal. 2003. Vol.37. No.7. P.36-40. (russian)

[10] O.M. Ipatova, N.N. Prozorovskaya, I.F. Rusina, V.N. Prozorovsky. Antioxidant properties of chokeberry leaf extract (Aronia melanocarpa) containing proanthocyanidins. Biomedical Chemistry. 2003. Vol.49. P.165-176. (russian)

[11] A.I. Konovalov, L.A. Ashaeva, R.Sh. Khaziev, A.A. Lapin, N.A. Sosnina, O.V. Tsepaeva, Sh.M. Yakubov. Protective properties of pectin substances Amaranthus cruentus. On Sat "Abstracts dokl. III Russian National Congress "Man and Medicine". (Moscow. Apr 16-20 1996). 1996. P.140. (russian)

[12] A. Mondal, T.K. Maity, D. Pal, S. Sannigrahi, J. Singh. Isolation and in vivo hepatoprotective activity of Melothria heterophylla (Lour.) Cogn. against chemically induced liver injuries in rats. Asian pac. $j$. top. med. 2011. Vol.4. No. 8. P.619-623. doi: 10.1016/S1995-7645(11)60159-4

[13] A.A. Lapin, N.A. Sosnina, V.V. Morozov, A.B. Vishtakaliuk, S.I. Strobikin, I.G. Mustafin, S.V. Boychuk, Y.V. Chugunov, I.Yu. Portnov and A.P. Zharkovskii. Therapeutic and prophylactic foodstuffs with plant polysaccharides - pectins. Chemistry and Computational Simulation. Butlerov Communications. 2001. No.5. (Code 1vr05). [Electronic Resource] - URL: http:// www.kstu.ru/jchem\&cs/english/n5/1vr05/\&1vr05.htm_(date of the address 3.04.2020). (russian)

[14] V.N. Zelenkov, A.A. Lapin. MVI-001-44538054-07. Total antioxidant activity. Method of measurement on the coolometric analyzer. Vegetable Growing. Verea, Moscow Region. 2013. 19p. (russian)

[15] TU 9369-141-04868244-07. Routine is a standard sample. Specification. (russian)

[16] State Pharmacopoeia of the USSR. Iss.2. General methods of analysis. Medicinal plant raw materials. MOH OF THE USSR. 11th ed., additional. Moscow: Medicine. 1989. 398p. (russian)

[17] Moda in statistics. [Electronic Resource] - URL: http:// statanaliz.info/statistica/opisanie-dannyx/moda/ (date of the address 3.04.2020). (russian)

[18] L.T. Kozayeva, A.A. Lapin, V.N. Zelenkov. The study of water and water-alcohol infusions of Filipendula Ulmaria. Unconventional natural resources, innovative technologies and products: Collection of scientific papers. Moscow: RAEN. 2007. Iss.15. P.72-76. (russian)

[19] A.I. Dar. Synergistic Hepatoprotective Effect of Feronia limonia L., Citrullus colocynthis L., and Tribulus terrestris L. against Paracetamol Induced Hepatotoxicity in Swiss Albino Rats. Journal of Pharmacy and Pharmacology. May, 2014. Vol.2. Iss.5. P.304-312.

[20] J. Katanić, T. Boroja, N. Stanković, V. Mihailović, M. Mladenović, S. Kreft and M.M. Vrvić. Bioactivity, stability and phenolic characterization of Filipendula ulmaria (L.) Maxim. Food Funct. 2015. Vol.6. P.1164-1175. Doi.org./10.1039/C4FO01208A. 